\title{
Development of laccase and manganese peroxidase biocathodes for microbial fuel cell applications
}

\author{
Sahar Bakhshian ${ }^{1}$, Hamid-Reza Kariminia ${ }^{1, *}$ \\ ${ }^{1}$ Department of Chemical and Petroleum Engineering, Sharif University of Technology, Tehran, Iran \\ *Corresponding author. Tel: +98 21 66166426, Fax: +98 21 66166426, E-mail: kariminia@sharif.ir
}

\begin{abstract}
In this study, we ivestigated how microbial fuel cell (MFC) performance can be affected by laccase and manganese peroxidase (MnP) enzymes as catalysts in the cathode compartment. Commercial laccase was immobilized by crosslinking on chitosan using glutaraldehyde. Immobilized enzyme was settled on graphite electrode previously covered with polymerized methylene blue. Application of this enzymatic electrode was investigated in the cathode chamber of a MFC. Output power density of the MFC in the mentioned situation was $100 \%$ higher than that for the graphite electrode. The MnP was first, produced from a white rot fungus isolate and was immobilized on the graphite electrode via adsorption. This modified electrode with MnP was utilized as cathode. The fuel cell with $\mathrm{MnP}$ modified graphite electrode and $\mathrm{H}_{2} \mathrm{O}_{2}$ as oxidizer yielded the maximum power density of $46 \mathrm{~mW} / \mathrm{m}^{2}$ at the current density of $109 \mathrm{~mA} / \mathrm{m}^{2}$. This augmentation of MFC performance was due to a higher cathode electrode potential with $\mathrm{H}_{2} \mathrm{O}_{2}$ rather than oxygen. The most important function of $\mathrm{MnP}$ was to catalyze the reduction of $\mathrm{H}_{2} \mathrm{O}_{2}$ and hence diminished activation overpotential loss of the cathode.
\end{abstract}

Keywords: Biocathode, Laccase, Manganese peroxidase, Microbial fuel cell

\section{Introduction}

Microbial fuel cells are devices that generate electricity by oxidation of organic substrates using bacterial metabolism. This technology is considered as a non-polluting and a new source of renewable energy $[1,2,3]$.

Oxygen is a preferable oxidant in the cathode compartment of MFC because of its availability and its environmental friendly reduction product i.e. water [4]. Platinum has been applied as main catalyst to improve oxygen reduction rate in the cathode chamber; but it imposes high cost on MFC construction [5].

Application of biocatalysts as an inexpensive alternative to platinum is a potential solution [4]. Application of these components under moderate (ambient) temperatures and neutral $\mathrm{pH}$ are the main advantages of them over conventional catalysts [6]. Laccase, bilirubin oxidase and peroxidase like manganese peroxidase $(\mathrm{MnP})$ has been used as biocatalysts in cathode of a MFC [6,7].

Laccase (E.C. 1.10.3.2, p-benzenediol: oxygen oxidoreductase) is a multi-copper oxidase enzyme in plants, fungi and some bacteria which can catalyze the oxidation of phenolic and other aromatic compounds resulting in four-electron reduction of oxygen to water [8]. The active site of laccase contains four cooper atoms as redox centers, classified in three types, $\mathrm{T}_{1}$, $T_{2}$ and $T_{3}$. The $T_{1}$ site is reduced by oxidation of substrate or involving in polarized electrode. Four electrons are transferred from $T_{1}$ site to $T_{2}$ and $T_{3}$ sites where, $\mathrm{O}_{2}$ is reduced to $\mathrm{H}_{2} \mathrm{O}[9,4]$. Palmore et al. have studied the application of fungal laccase in the cathode compartment of a dihydrogen/dioxygen biofuel cell. Reduction of dioxygen to water with laccase was mediated by redox mediator, 2,2'-azinobis (3-ethylbenzothiazoline-6-sulfonate). They concluded that a biocatalyst with specific activity of $10^{3} \mathrm{U} / \mathrm{mg}$ has a higher catalysis rate than a platinum as catalyst in the cathode compartment [4]. 
Manganese peroxidase (MnP) (EC 1.11.1.13) is one of the major ligninolytic enzymes that can be produced by white rot fungi. This enzyme is a heme containing glycoprotein that uses hydrogen peroxide as oxidant and reduce it to water $[10,11]$.

In this study, methylene blue was electropolymerized on graphite electrode as an electrical active polymer that can enhance electron transfer. Commercial laccase was immobilized by crosslinking on chitosan with glutaraldehyde. Immobilized laccase was settled on a graphite electrode covered with polymethylene blue and this enzymatic electrode was applied in a dual chamber MFC as cathode electrode. In another attempt, MnP produced from a white rot fungus isolate was immobilized on graphite electrode via adsorption. Effect of this biocathode electrode was also investigated on the MFC performance.

\section{Methodology}

\subsection{Microbial fuel cell assembly}

The MFC setup consisted of two $250 \mathrm{ml}$ chambers joined through a short tube. Nafion 117 was utilized as membrane with $1.5 \mathrm{~cm}$ diameter separating two compartments. Pretreatment of the membrane was conducted by soaking it in a $0.1 \mathrm{M} \mathrm{H}_{2} \mathrm{SO}_{4}$ solution, $\mathrm{H}_{2} \mathrm{O}_{2}$ solution and deionized water, each for $60 \mathrm{~min}$ at $60^{\circ} \mathrm{C}$. Anode and cathode electrodes were $6 \mathrm{~cm} \times 2 \mathrm{~cm}$ and $4 \mathrm{~cm} \times 2 \mathrm{~cm}$ graphite bars, respectively. These two electrodes were connected with a copper wire. The anode chamber was inoculated with anaerobic sludge and both chambers were mixed gently by a magnetic stirrer.

Nutrient medium ( $\mathrm{pH}$ 7) utilized in the anode chamber consisted of molasses $(1 \mathrm{~g} / \mathrm{l})$, $\mathrm{K}_{2} \mathrm{HPO}_{4}$, urea and trace elements $\left(0.4 \mathrm{mg} / 1 \mathrm{FeCl}_{3}, 3 \mathrm{mg} / 1 \mathrm{MgSO}_{4}, 0.11 \mathrm{mg} / 1 \mathrm{CuSO}_{4} .5 \mathrm{H}_{2} \mathrm{O}\right.$, $0.7 \mathrm{mg} / \mathrm{l} \mathrm{NaCl}, 0.015 \mathrm{mg} / \mathrm{l} \mathrm{ZnCl}{ }_{2}, 4 \mathrm{mg} / 1 \mathrm{Na}_{2} \mathrm{~S}_{2} \mathrm{O}_{5}, 0.254 \mathrm{mg} / \mathrm{l} \mathrm{MnSO}_{4} \cdot \mathrm{H}_{2} \mathrm{O}, 2.06 \mathrm{mg} / \mathrm{l}$ $\left.\mathrm{FeSO}_{4} .7 \mathrm{H}_{2} \mathrm{O}\right)$. All experiments were performed at the ambient temperature $\left(28 \pm 1^{\circ} \mathrm{C}\right)$.

\subsection{Microorganism and enzyme}

Commercial laccase was prepared from AB Enzymes GmbH, Germany.

A lignolytic fungus isolated from rotted wood in Northern Iran was employed for the production of MnP. This isolate had indicated the capability to produce $\mathrm{MnP}$ as its main lignolytic enzyme. As much as $50 \mathrm{ml}$ of the culture broth $(30 \mathrm{~g} / 1 \mathrm{glucose}, 10 \mathrm{~g} / \mathrm{l}$ peptone, $5 \mathrm{~g} / \mathrm{l}$ yeat extract and $0.1 \mathrm{mM} \mathrm{Mn}{ }^{2+}, \mathrm{pH}$ 4) was prepared in $250 \mathrm{ml}$ Erlenmeyer flasks and autoclaved $\left(121^{\circ} \mathrm{C}, 15 \mathrm{~min}\right)$. One mycelia piece of the isolated fungus was placed in the center of an autoclaved $3.9 \%$ potato dextrose agar plate and incubated at $32^{\circ} \mathrm{C}$. After 7 days of cultivation, a mycelial plug (diameter $10 \mathrm{~mm}$ ) of this culture was used as the inoculum. The cultivation was conducted in a rotary shaker with the rotation speed of $160 \mathrm{rpm}$ at $32^{\circ} \mathrm{C}$. After 14 days, when a maximum activity for the extracellular MnP was observed, the enzyme was collected from the culture broth by centrifugation $(5,000 \mathrm{rpm}$ for $30 \mathrm{~m} \mathrm{in})$. The supernatant then was utilized for immobilization on the graphite electrode.

\subsection{Preparation of enzymatic biocathodes}

Electropolymerization of methylene blue was performed by cyclic voltammetery using a potentiostat - galvanostat EG\&G PAR 273A, Princeton Applied Research, US from -0.5 to $1.2 \mathrm{~V}$ for 18 scans at a scan rate of $50 \mathrm{mV} / \mathrm{s}$ [13]. Electrolyte solution contained $0.01 \mathrm{M}$ borate buffer ( $\mathrm{pH}$ 9.1), 0.1 $\mathrm{M} \mathrm{NaNO}_{3}$ and $0.4 \mathrm{~m} \mathrm{M}$ methylene blue. In another study, the optimal monomer concentration was found to be $0.4 \mathrm{mM}$. As basic electrolyte solution, $0.1 \mathrm{M} \mathrm{NaNO}_{3}$ was used. Nitrate ions have catalytic role on electropolymerization of methylene blue. Graphite electrode $\left(12 \mathrm{~cm}^{2}\right)$ was polished with emery paper and rinsed with distilled water 
prior to use. The reference and counter electrodes were saturated calomel electrodes (SCE, $0.241 \mathrm{~V}$ vs. SHE) and platinum sheet $\left(2 \mathrm{~cm}^{2}\right)$, respectively.

Crosslinking method was employed for laccase immobilization. The enzyme was immobilized on chitosan using glutaraldehyde [12]. A $5 \mathrm{~g} / 1$ chitosan solution was prepared using a $2 \%$ acetic acid solution to dissolve chitosan. By addition of $2 \mathrm{M} \mathrm{NaOH}$ to this solution, a white flocculent deposit was formed and separated from the wet chitosan carrier. The flocculent was washed with distilled water several times and then $20 \mathrm{ml}$ of a $5 \%$ glutaraldehyde solution was added. In order to associate the glutaraldehyde to the enzyme, the solution was mixed for $8 \mathrm{~h}$ and then left overnight. After that, the deposit was washed with water and added to $50 \mathrm{ml}$ of a $20 \mathrm{~g} / 1$ laccase solution. Then, $5 \mathrm{ml}$ of acetate buffer ( $\mathrm{pH} \mathrm{4.4)}$ was added to the solution, agitated for $16 \mathrm{~h} \mathrm{a} \mathrm{t}$ room temperature and incubated at $4^{\circ} \mathrm{C}$, overnight. The resulting settlement was immobilized laccase on chitosan. Then, $1 \mathrm{ml}$ of the immobilized laccase on chitosan was pipetted onto the electropolymeried (polymethylene blue) graphite electrode and left to dry in a vacuum desiccator for 1 hour. Glutaraldehyde molecule includes two aldehyde group $(-\mathrm{CHO})$ in its structure in which one of these groups react with amine group $\left(-\mathrm{NH}_{2}\right)$ of chitosn and crosslinking takes place. The free aldehyde group of glutaraldehyde bounds to an amine group of laccase, covalently. Therefore, glutaraldehyde plays the crosslinking agent role in the linkage of laccase to chitosan.

$\mathrm{MnP}$ was immobilized to the graphite electrode by adsorption. As much as $1 \mathrm{ml}$ of the produced crude $\mathrm{MnP}$ was pipetted onto the graphite electrode and left to dry in a vacuum desiccator for 1 hour.

\subsection{Laccase and MnP activity assay}

Laccase activity measurement was performed spectrophotometrically at $25^{\circ} \mathrm{C}$, using 2,2azino-bis-(3-ethylbenzothiazoline-6-sulfonic acid) or ABTS as substrate. The mixture of reaction was contained $3 \mathrm{ml}$ sodium acetate buffer $(1 \mathrm{mM}, \mathrm{pH} 4.5), 0.1 \mathrm{ml}$ ABTS $(0.5 \mathrm{mM})$ and $0.1 \mathrm{ml}$ enzyme solution. The reaction started by addition of ABTS solution $(0.1 \mathrm{ml})$. The rate of $\mathrm{ABTS}^{+}$formation was measured spectrophotometrically at $420 \mathrm{~nm}$. One unit of the enzyme activity (U) determined as the amount of the enzyme necessary to produce $1 \mu \mathrm{mol}$ of oxidized ABTS per minute [14].

$\mathrm{MnP}$ was assayed by the formation of $\mathrm{Mn}^{3+}$ in $50 \mathrm{mM}$ sodium malonate buffer ( $\mathrm{pH} 4.5$ ), using $0.1 \mathrm{Mm} \mathrm{H}_{2} \mathrm{O}_{2}$ as substrate. The rate of complex formation between manganic ions $\mathrm{Mn}^{3+}$ and malonate was measured specrophotometrically at $270 \mathrm{~nm}$. One unit of $\mathrm{MnP}$ activity defined as the amount of the enzyme necessary to produce $1 \mu \mathrm{mol}$ of $\mathrm{Mn}^{3+}$ per minute at $25^{\circ} \mathrm{C}$ [15].

\section{Results and Discussion}

\subsection{Electropolymerization of methylene blue on graphite}

Methylene blue was polymerized on the surface of a graphite electrode. According to cyclic voltammogram of polymethylene blue on the graphite (Fig. 1), the picks appeared at high anodic potential (almost $1 \mathrm{~V}$ ) are related to the irreversible oxidation of the monomer. Other picks are formed due to polymerization of formed cation radicals of methylene blue. Therefore, after oxidation of methylene blue and formation of radicals, chemical reaction related to the polymerization of these radicals had been taken place. Methylene blue which is an electroactive polymer was utilized as a mediator due to its high conductivity. Polymethylene blue could increase electron transfer from the electrode to active sites of the laccase. Therefore, electron access will be improved after polymerization of methylene blue 
on the electrode surface. As a result, mediator utilization will influence oxygen reduction to water, catalyzed by the laccase in the cathode compartment.

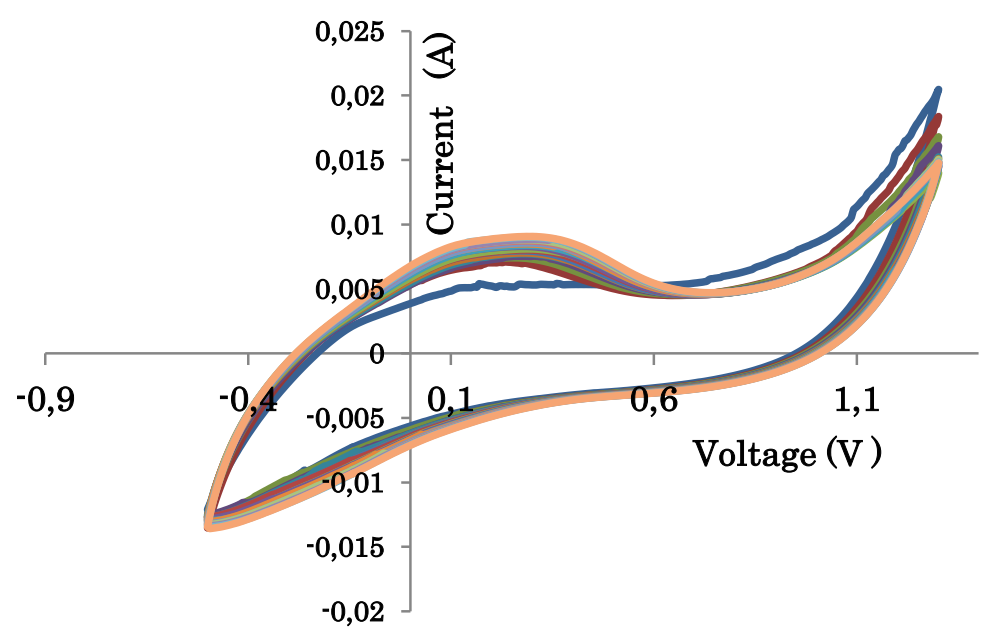

Fig 1. Cyclic voltagram of methylene blue on graphite electrode (Scan rate $50 \mathrm{mV} / \mathrm{s}$ ).

\subsection{MFC performance in the presence of laccase}

The polarization curve that was obtained by changing the external load at the maximum output voltage of the MFC, indicates the cell voltage drop and power dependence on current. In general, power density increases to a maximum value against current density and then sharply decreases. Polarization and power curve of the cathode electrodes were plotted at the maximum voltage of the MFC when each of graphite, polymerized graphite or enzymatic electrode was used.

The polarization curves of graphite, polymerized graphite and laccase immobilized graphite are shown in Fig. 2. Maximum current density of the MFC for the polymerized graphite as cathode was $20 \%$ higher than that for the graphite electrode. This increase in the current density is due to electron transfer improvement because of improved conductivity of the polymerized graphite electrode.

The power curves of graphite, polymerized graphite and laccase immobilized graphite are indicated in Fig. 3. The maximum power density for the enzymatic electrode was 45.2 $\mathrm{mW} / \mathrm{m}^{2}$ at the current density of $175 \mathrm{~m} \mathrm{~A} / \mathrm{m}^{2}$, which was two folds of that for the graphite electrode (maximum power density of $22.3 \mathrm{~mW} / \mathrm{m}^{2}$ at current density of $106.9 \mathrm{~mA} / \mathrm{m}^{2}$ ). The maximum power density for the polymerized graphite electrode was $31 \mathrm{~mW} / \mathrm{m}^{2}$ at the current density of $140.6 \mathrm{~mA} / \mathrm{m}^{2}$. The power density improved $40 \%$ in comparison to the graphite electrode. The maximum power density for graphite, polymerized and enzymatic graphite occurred at the external load of 1.2, 98 and $92 \mathrm{k} \Omega$, respectively. According to Ohm's law, at maximum power density, external load is equal to the internal load of MFC. Therefore, modification of graphite electrode through electropolymerization and enzyme immobilization causes a reduction in the internal resistance of the MFC. This phenomenon occurs due to the improvement of electron transfer when polymerized methylene blue or laccase is used on the graphite electrode and the internal resistance of the system decreases, accordingly.

Fig. 3 also indicates that the slope of polarization curve for the enzymatic electrode is milder than that for the graphite electrode at lower current densities. This observation suggests that the activation overpotential of the enzymatic electrode is less than the graphite electrode. 


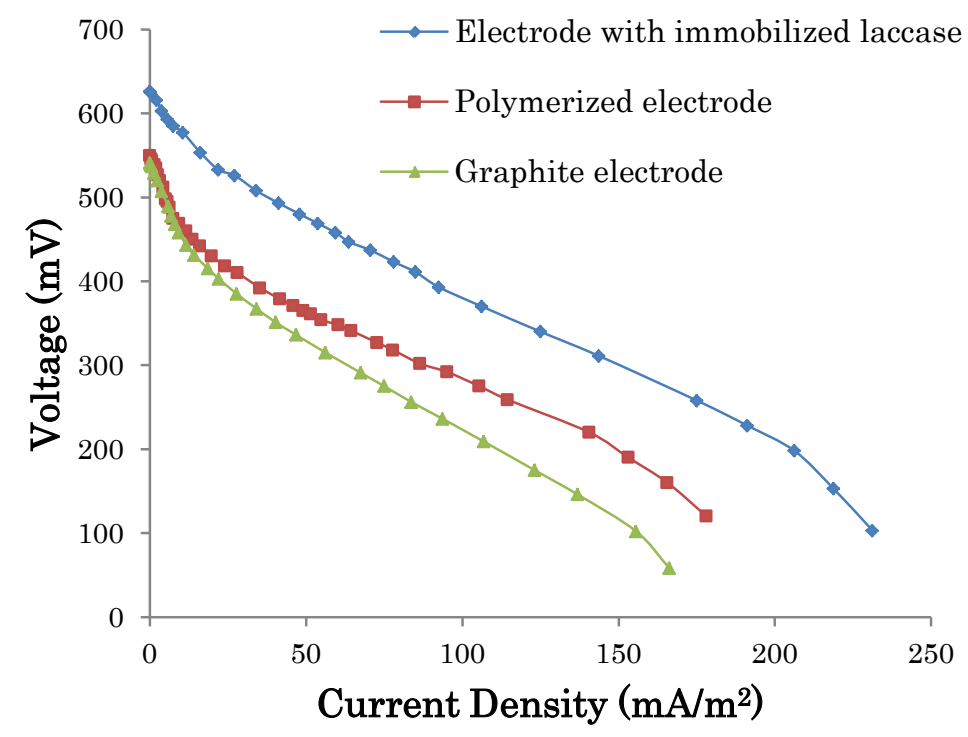

Fig. 2. Polarization curve of MFC with three different electrodes.

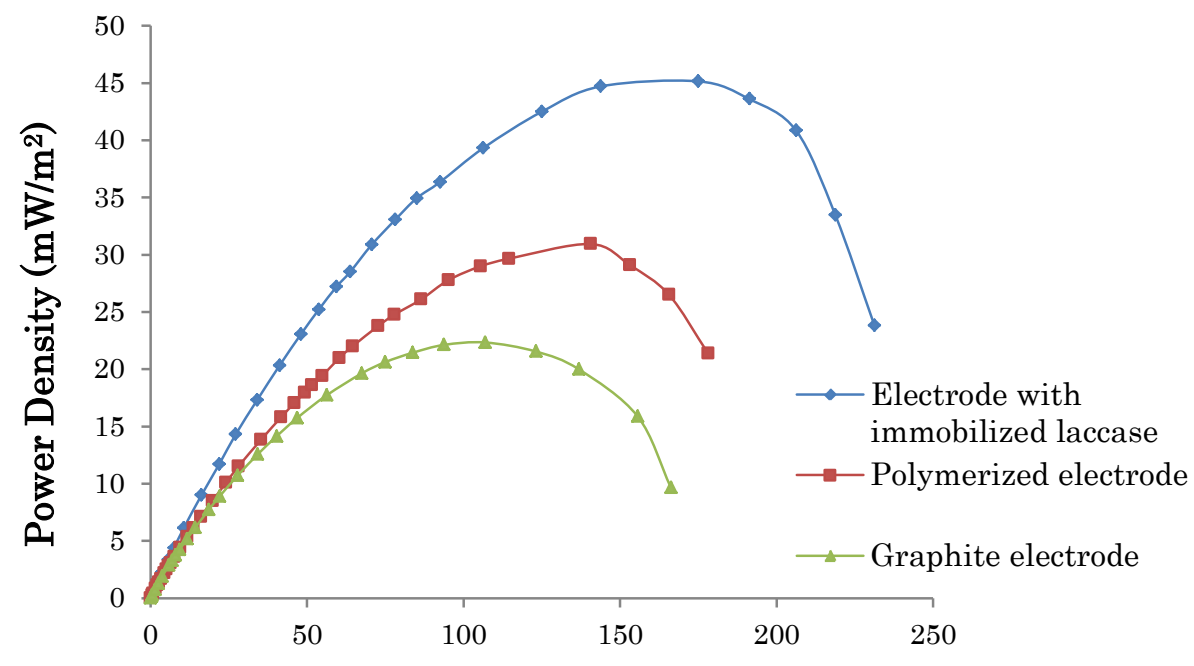

Current Density $\left(\mathrm{mA} / \mathrm{m}^{2}\right)$

Fig. 3. Power density curve of MFC with three different.

\subsection{MFC performance in the presence of MnP}

The time course of open circuit voltage variation of the MFC after addition of $\mathrm{H}_{2} \mathrm{O}_{2}$ is shown in Fig. 4. After $\mathrm{H}_{2} \mathrm{O}_{2}$ addition, the voltage rapidly increased to a maximum value and then gradually decreased to a constant value. The voltage increase is related to a higher cathodic potential of $\mathrm{H}_{2} \mathrm{O}_{2}$ compared to oxygen potential. The MFC performance during this stable condition is shown in the polarization and power curves (Fig. 5 and Fig. 6). Maximum output power of $46 \mathrm{~mW} / \mathrm{m}^{2}$ was obtained at current density of $108.8 \mathrm{~mA} / \mathrm{m}^{2}$. This power density is $106 \%$ higher than that for a non-enzymatic cathode. The slope of polarization curve for $\mathrm{MnP}$ with immobilized MnP cathode at low current densities is $54 \%$ less than that for the nonenzymatic cathode. Therefore, $\mathrm{MnP}$ presence in the cathode reduces cathodic and overall activation overpotential which is attributed to the catalytic role of $\mathrm{MnP}$ in the cathode. 


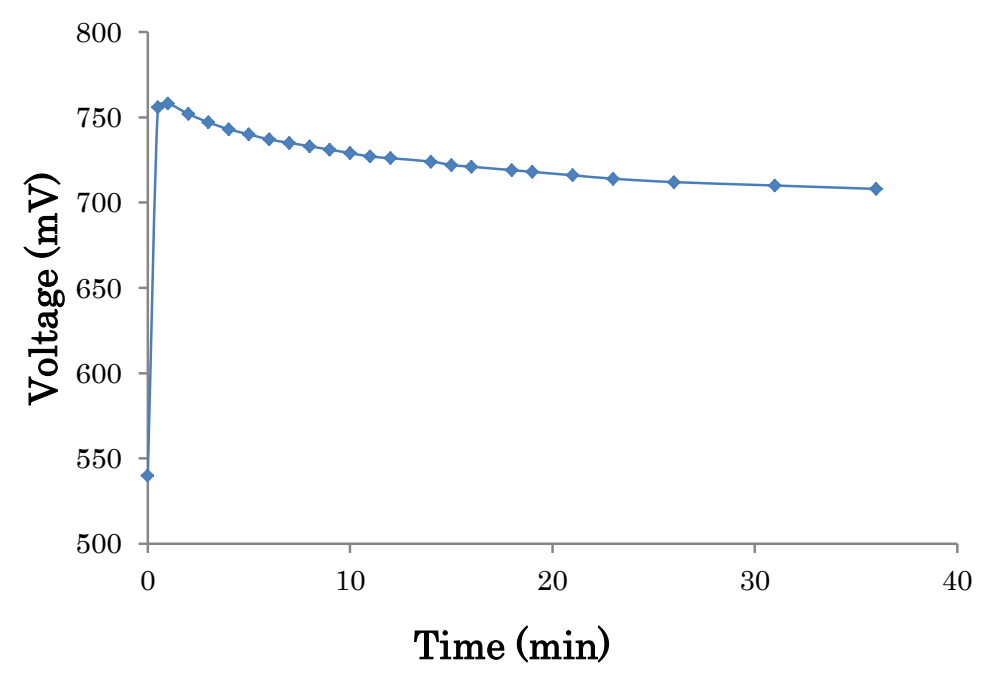

Fig. 4. Open circuit voltage-time curve of MFC after $\mathrm{H}_{2} \mathrm{O}_{2}$ addition to the cathode in the presence of $\mathrm{MnP}$.

$\mathrm{MnP}$ can catalyze hydrogen peroxide reduction to water. Reduction of $\mathrm{H}_{2} \mathrm{O}_{2}$ causes the oxidation of heme group of the enzyme. The oxidized heme group needs to be reduced to keep its activity which can be fulfilled electrochemically or by an electron donor molecule. Here, $\mathrm{Mn}^{2+}$ acts as electron donor. Electrons generated through $\mathrm{Mn}^{2+}$ oxidation will be transferred to the active sites of the enzyme and will be utilized to reduce $\mathrm{H}_{2} \mathrm{O}_{2}$ to water. The produced $\mathrm{Mn}^{3+}$ ions extract electrons presented on the cathode surface. The cathodic reaction is catalyzed by $\mathrm{MnP}$ enzyme through repetition of the mentioned reactions, cyclically.

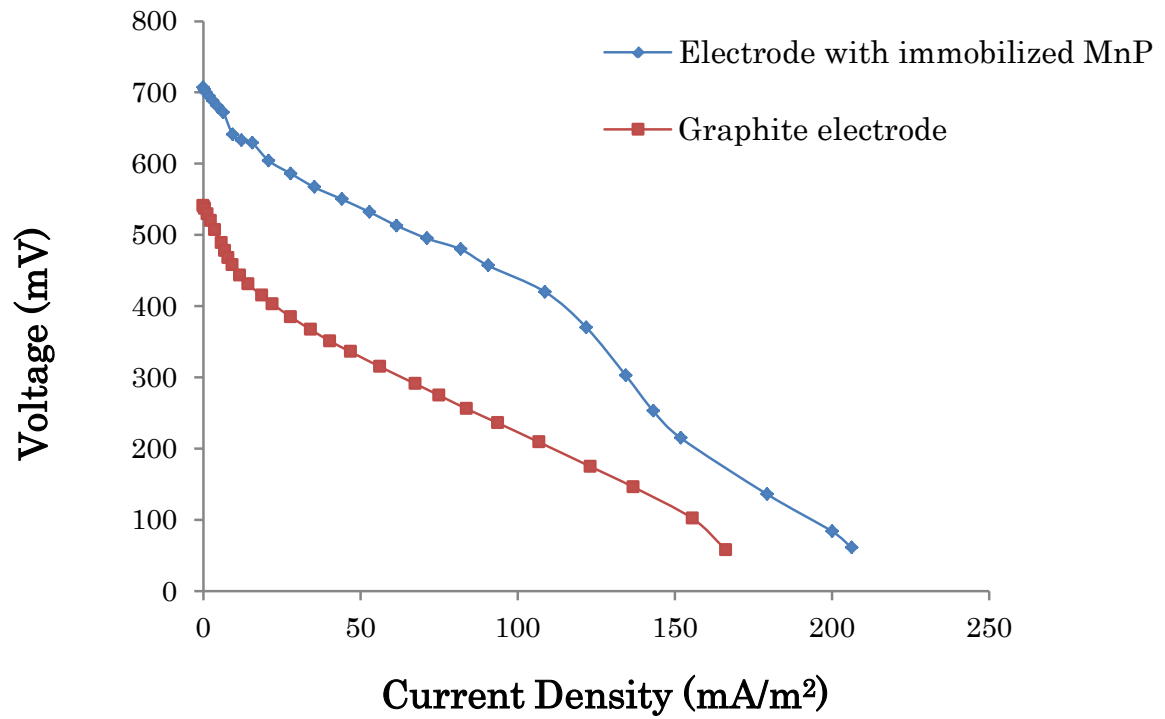

Fig. 5. Polarization curve of MFC with two different electrodes. 


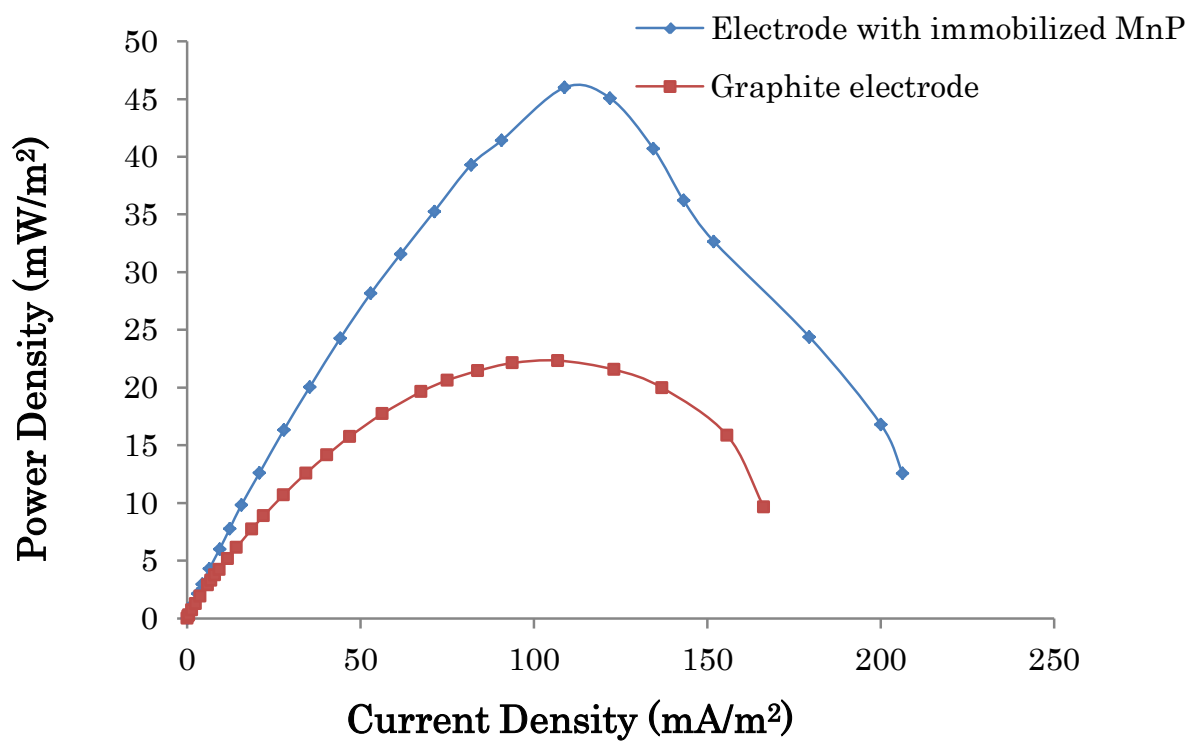

Fig. 6. Power density curve of MFC with three different electrodes.

\section{Conclusion}

Commercial laccase and $\mathrm{MnP}$ produced from a white rot fungus isolate were immobilized on graphite electrode and used as new renewable catalysts in the cathode compartment of a dual chamber MFC. Application of these electrodes in the cathode, enhanced the MFC performance. Output voltage and current density increased as two times as output voltage of the MFC with non-enzymatic cathode. Activation overpotential of MFC decreased due to the catalytic effect of laccase and $\mathrm{MnP}$ on reduction of oxygen and $\mathrm{H}_{2} \mathrm{O}_{2}$, respectively. Laccase and $\mathrm{MnP}$ can be proposed as innovative catalysts to be applied in MFCs in order to achieve higher performance via improvement of reaction kinetic in the cathode and therefore, reduction of its related overpotential.

\section{References}

[1] B.E. Logan, B. Hamelers, R. Rozendal, U. Schröder, J. Keller, S. Freguia, P. Aelterman, W. Verstraete and K. Rabaey, Microbial fuel cells: methodology and technology, Environmental Science and Technology, 2006, pp. 307-314.

[2] Z.-D. Liu, H.-R. Li, Effects of bio- and abio-factors on e lectricity production in a mediatorless microbial fuel cell, Biochemical Engineering Journal, 2007, pp. 209-214.

[3] R.D. Lovely, Microbial fuel cells: novel microbial physiologies and engineering approaches, Current Opinion in Biotechnology, 2006, pp. 327-332.

[4] G. Tayhas, R. Palmore, H.H. Kim, Electro-enzymatic reduction of dioxygen to water in the cathode compartment of a biofuel cell, Journal of Electroanalytical Chemistry, 1999, pp. 110-117.

[5] O. Lefebvre, W.K. Ooi, Z. Tang, Md. Abdullah-Al-Mamun, D.H.C. Chua, H.Y. Ng, Optimization of a Pt-free cathode suitable for practical applications of microbial fuel cells, Bioresource Technology, 2009, pp. 4907-4910.

[6] M. Smolander, H. Boer, M. Valkiainen, R. Roozemana, M. Bergelin, J. E. Eriksson, X. C. Zhang, A. Koivula, L. Viikari, Development of a printable laccase-based biocathode for fuel cell applications, Enzyme and Microbial Technology, 2008, pp. 93-102. 
[7] R.A. Bullen, T.C. Arnot, J.B. Lakeman, F.C. Walsh, Biofuel cells and their development, Biosensors and Bioelectronics, 2006, pp. 2015-2045.

[8] N. Duran, M. Rosa, A.D. Annibale, L. Gianfreda, Application of laccases and tyrosinases (phenoloxidases) immobilized on di fferent supports: a review, Enzyme and Microbial Technology, 2002, pp. 907-931.

[9] C. Vaz-Dominguez, S. Campuzano, O. Rudiger, M. Pita, M. Gorbacheva, S. Shleev, V. M. Fernandez, A.L.D. Lacey, Laccase electrode for direct electrocatalytic reduction of $\mathrm{O}_{2}$ to $\mathrm{H}_{2} \mathrm{O}$ with high-operational stability and resistance to chloride inhibition, Biosensors and Bioelectronics, 2008, pp. 531-537.

[10] H.-R. Kariminiaae-Hamedaani, A. Sakurai, M. Sakakibara, Decolorization of synthetic dyes by a new manganese peroxidase-producing white rot fungus. Dyes and Pigments, 2007, pp. 157-162.

[11] M. Hofrichter, Review: lignin conversion by manganese peroxidase (MnP), Enzyme and Microbial Technology, 2003, pp. 454-466.

[12] J. Zhang, Z. Xu, H. Chen, Y. Zong, Removal of 2,4-dichlorophenol by chitosanimmobilized laccase from Coriolus versicolor, Biochemical Engineering Journal, 2009, pp. 54-59.

[13] A.A. Karyakin, E.E. Karyakina, H.-L. Schmidt, Electropolymerized azines: a new group of electroactive polymers, Electroanalysis, 1999, pp. 149-155.

[14] X.Q. Yang, X.X. Zhao, C.Y. Liu, Y. Zheng, S.J. Qian, Decolorization of azo, triphenylmethane and anthraquinone dyes by a newly isolated Trametes sp. SQ01 and its laccase, Process Biochemistry, 2009, pp. 1185-1189.

[15] H. Wariishi, K. Valli, MH. Gold, Manganese (II) oxidation by manganese peroxidase from the basidiomycete Phanerochaete chrysosporium, Journal of Biological Chemistry, 1992, pp. 23688-23695. 